\title{
The structure of the ophiolitic belt in Albania inferred from geomagnetic anomalies
}

\author{
Ilir Kane $\left({ }^{1}\right)$, Alexandros Stampolidis $\left({ }^{1}\right)$, N. Grigoris Tsokas $\left({ }^{1}\right)$, Salvatore Bushati $\left({ }^{2}\right)$, \\ Despoina Kondopoulou $\left({ }^{1}\right)$ and Panagiotis Tsourlos $\left({ }^{1}\right)$ \\ (') Department of Geophysics, School of Geology, Aristotle University of Thessaloniki, Greece \\ ${ }^{(2)}$ Centre of Geophysical and Geochemical Exploration (CGGE), Tirana, Albania
}

\begin{abstract}
The ground magnetic measurements in Albania were used for the compilation of the Total Magnetic Field (TMF) anomaly map of Albania. The magnetic data were processed and interpreted in order to study the structure of the ophiolitic belts of Albania. The ophiolites of Albania are placed at the Mirdita zone and are divided into two parallel alignments which are called the eastern and western ophiolitic belts. They are associated with strong potential field anomalies and their characteristics are considered crucial for a better understanding of the tectonic settings of Albania. The ground TMF data used in this study were acquired over various campaigns (1990-1994) and cover most of Albania's territory. The data were compiled to a map after reduction to the epoch 1990.4. The strongest magnetic anomalies in Albania appear along the known ophiolitic belts which trend NE-SW to the north and NW-SE to the south. Several processing steps were applied to the unified and gridded data in order to obtain information on the distribution of the magnetic sources. The magnetic sources were subsequently modeled using a 2.5D inversion technique. The magnetic properties of the ophiolites determined from laboratory measurements on rock samples, while their lateral extent was calculated from the processing of the magnetic data and used as constraints to the inversion procedure. The bottom of the ophiolitic belts is considered to be predominated by harzburgites. They exhibit lower magnetization than other rocks of the complex, i.e. gabbros, basalt. In fact gabbros are associated with the observed high frequency magnetic anomalies. The modeling results indicate that the thickness of the ophiolites is reduced from east to west. The eastern ophiolitic belt has a maximum thickness of approximately $12 \mathrm{~km}$ at its northern section (Kukesi and Lura massifs). The magnetic sources appear with relatively small thickness at the western ophiolitic belt. Boundaries of the eastern ophiolites are characterized by vertical contacts.
\end{abstract}

Key words Total Magnetic Field - ophioltic belt $2.5 \mathrm{D}$ modelling - Albania

\section{Introduction}

The existing studies of the potential fields in Albania are mainly restricted to an analysis

Mailing address: Dr. Alexandros Stampolidis, Department of Geophysics, School of Geology, Aristotle University of Thessaloniki, P.O. Box 352-1, Thessaloniki, GR54124 Greece; e-mail: astamp@lemnos.geo.auth.gr of the ground gravimetric data rather than the geomagnetic data (Lubonja et al., 1977; Arapi, 1982; Bushati, 1988; Frasheri et al., 1991; Veizaj, 1995). Frasheri et al. (1995) present results from some potential field interpretations and their relation to the regional geologic problems. Veizaj (1995) presents a model of the crust based on some gravimetric profiles across Albania also using the interpretation of the Bouguer anomaly map of Albania and the free air data of Adriatic Sea. Bushati (1988) compiled the Bouguer anomaly map of Albania and related the gravity high at the Midrita zone to the moderately serpentinized mantle 
rocks there. Bushati et al. (1996) suggested that the ophiolites have thicknesses varying from 10-14 km at the NE part of the ophiolitic belt to $6 \mathrm{~km}$ at the south-eastern Bulqiza Mas- sif. The western ophiolites are typically only 2-3 km thick.

The measurements of the geomagnetic field in Albania consist mostly of regional datasets
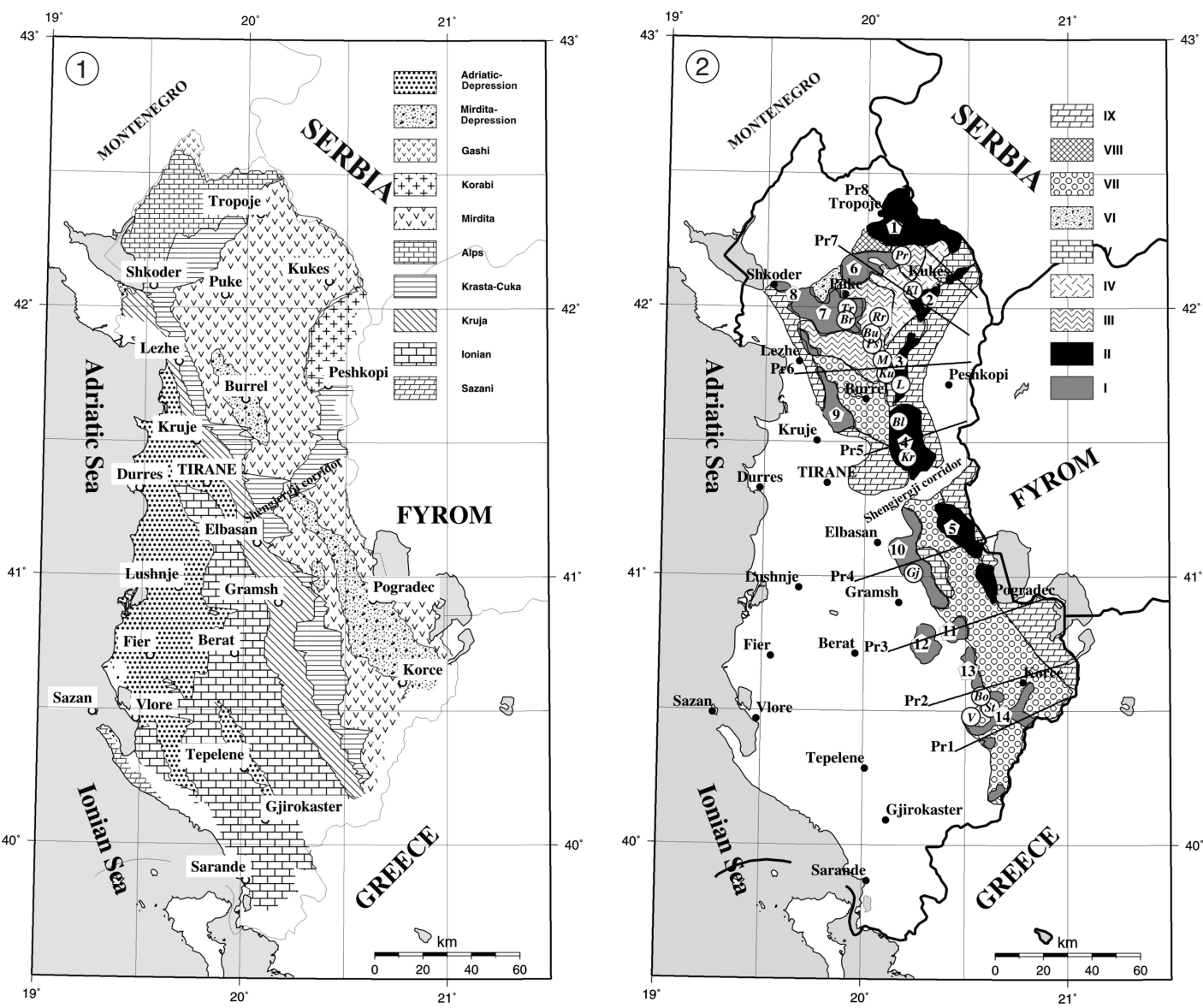

Fig. 1. Simplified geologic map of Albania with the sample sites at the ophiolitic rocks. The tectonic zones are: Sazani, Ionian, Kruja, Krasta-Cukali, Alps, Mirdita, Korabi, Gashi, depression of Mirdita zone and Peri-Adriatic depression.

Fig. 2. A simplified geologic map of Mirdita zone. I - western belt; II - eastern belt; III - volcanic rocks; IV - gabbros; V - Cretaceous limestones; VI - Tithonian breccia; VII - Paleocene Quaternary sedimentary rocks; VIII - Heterogeneous ophiolitic mélange; IX - Upper Triassic-Lower Jurassic limestones. The codes in the cycles taken from table I and denote the sites where the rock samples were extracted for laboratory measurements. The numbers in polygons denote the ophiolitic massifs. 1 - Tropoja; 2 - Kukesi; 3 - Lura; 4 - Bulqiza; 5 - Shebeniku-Pogradec; 6 - Krrabi; 7 - Terbuni; 8 - Gomsiqe; 9 - Skenderbeu; 10 - Shpati; 11 - Vallamara; 12 - Devolli; 13 - Voskopoja; 14 - Morava. The location of the eight profiles, where 2.5D modeling was attempted, is shown as well (i.e. $\operatorname{Pr} 1-\operatorname{Pr} 8)$. 


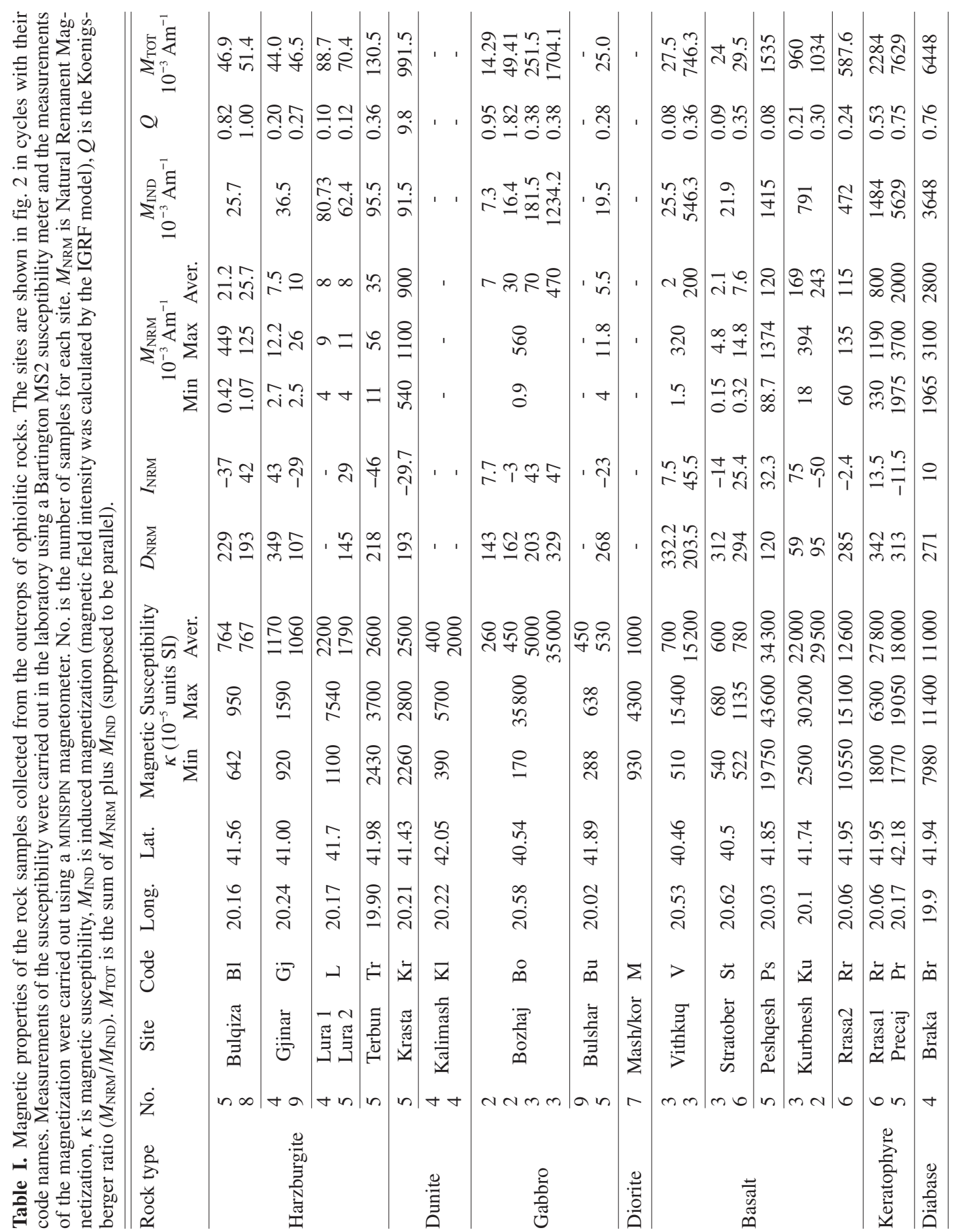


measured over limited areas for mineral exploration purposes. Further, measurements were carried out to map regions that include the ultramafic massifs (Angelopoulos and Bushati, 1993). The total magnetic field and the vertical component were measured on some profiles across Albania (Geology of Albania, 1982). However, they comprised a small number and they were rather sparse to give an idea on the distribution of the geomagnetic sources in Albania and no modelling was attempted.

The main subsurface magnetic sources in Albania are the ophiolites which are mainly located at the Mirdita zone (fig. 1). The ophiolitic rocks of the Mirdita zone generate very distinguishable magnetic anomalies compared to those of the surrounding sedimentary rock formations. Thus, the study of the magnetic field is considered a useful tool for the structural investigation of the ophiolites in Albania.

In this work the existing ground geomagnetic data were compiled to produce a map of the magnetic field of Albania. Different filters and transformations were applied to the gridded data in order to obtain information about the distribution of the magnetic sources. Also, interpretation methods such as «terracing» and 2.5D inversion were employed to reconstruct the magnetic sources along selected profiles perpendicular to the ophiolitic belts. The results compared with other geophysical studies (Bushati, 1988; Bushati et al., 1996) and existing geological information, hopefully contribute to the study of ophiolites in Albania.

\section{Geological setting}

The Albanides represent the assemblage of geological structures that lie in the territory of Albania. They are located between the Dinarides in the north and the Hellenides in the south. Together they form the Dinaric branch of the Mediterranean Alpine belt. The Albanides are divided into Internal (east) and External (west) zones and between them extends the Midrita zone. The Internal Albanides are characterized by the continental formations of the Korabi(Pelagonian in Greece) zone, while the external zones by a continuous sedimentation and defor- mation from Triassic to Paleogene times. The External Albanides are the Krasta-Cukali and the Kruja zones, corresponding to the Pindos and Gavrovo nappes in Greece respectively, and the Ionian and Sazani zones (fig. 1), (Aubouin, 1959; Geology of Albania, 1982). The Central Midrita zone comprises mainly ophiolites as early mentioned.

The Midrita zone ophiolites (fig. 2) form a broad, westward-convex arc, $c a$. $250 \mathrm{~km}$ long and up to $70 \mathrm{~km}$ wide, with an outcrop area of approximately $4000 \mathrm{~km}^{2}$ (7000 $\mathrm{km}^{2}$ if the sedimentary cover is excluded). They belong to the SSE trending Dinaric mountainous system (Nowack, 1929) and link Dinaric ophiolites with Hellenic ophiolites (Aubouin and Ndojaj, 1964). The Midrita zone represents an oceanic lithosphere segment one of the most complete and coherent sequences among the Mediterranean ophiolites and is constituted by NNWSSE trending sub-parallel belts.

In the Mediterranean Alpine belts, a western lherzolite ophiolite belt, comprising the Midrita ophiolite, and an eastern harzburgite belt (Vardar) were distinguished in the early literature (Nicolas and Jackson, 1972). Based on petrological variability, geochemical and metallogenic studies, a western-type lherzolitic belt and an eastern-type harzburgitic belt have been distinguished in the Midrita ophiolite itself (Ndojaj, 1963; Dede et al., 1966; Tashko, 1976; Shallo et al., 1985, 1989; Shallo, 1992; Beccaluva et al., 1994; Robertson and Shallo, 2000) (fig. 2). The eastern-type ophiolitic belt includes the Tropoja, Kukesi, Lura, Bulqiza, Shebeniku-Pogradec massifs, while the main massifs of the western-type belt are the Krrabi, Terbuni, Gomsiqe, Kashnjet, Skenderbeu, Kuturumani, Shpati, Devolli and Morava massifs. Summary logs of the western and eastern-type ophiolites of Midrita zone are presented in fig. 3 (Robertson and Shallo, 2000).

The western-type ophiolites (Triassic-Jurassic) - This belt is relatively thin ( $c a .2-3 \mathrm{~km})$ and consists of high-Ti tholeiites within volcano-sedimentary series in the western peripheral parts and a volcanic sequence in the western part, associated with lherzolite mantle suite and minor harzburgite and dunite tectonite and 


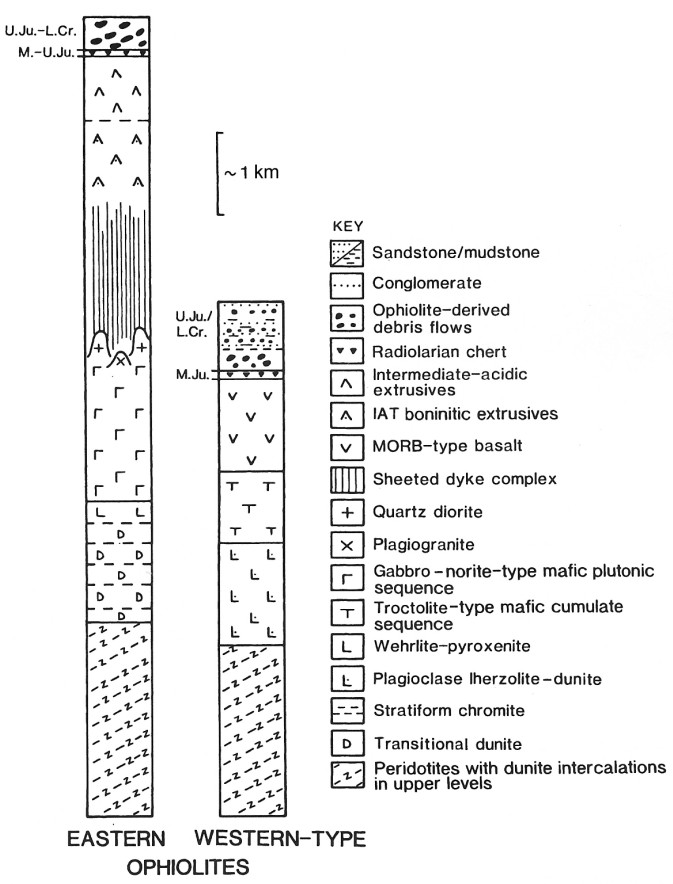

Fig. 3. Summary logs of the western and eastern ophiolites, Midrita zone (Robertson and Shallo, 2000).

ultramafic and mafic cumulates (Shallo et al., 1985; Beccaluva et al., 1994; Hoxha, 2001). They are disrupted into a series of large thrust sheets and substantial detached blocks that are mainly eastward-dipping, to steeply inclined, folded and cut by steep faults. Ophiolitic volcanics and sedimentary cover units are preserved in kilometre-scale synclines in Northern Albania (Robertson and Shallo, 2000).

The eastern-type ophiolites (Jurassic) - This belt is characterized by low-Ti tholeiites of basalt-andesite and andesite-dacite (rhyolite) series underlain by sheeted dyke complex, and quartzdiorite-plagiogranite and gabbros (ISPGJIGJN, 1982; Shallo et al. 1985; Beccaluva et al., 1994; Hoxha, 2001). Ultramafic mantle sequences are represented by clinopyroxene-poor harzburgite, overlain by harzburgite-dunite and both interbedded with and overlain by thick transitional dunite, rare wehrlite-lherzolite and cumulate pyroxenite. The eastern-type ophiolites reveal a major thrust sheet, 6-8 $\mathrm{km}$ thick, segmented into several large massifs. The existence of a stack of thrust sheets in the easterntype ophiolite indicates that they were internally disrupted. Triassic limestone blocks along the front of the biggest thrust and sub-alkali volcanites (not belonging to the ophiolite series) in the center of the ophiolites indicate the presence of exotics emplaced during the Late Jurassic-Early Cretaceous ophiolite obduction, and are possibly derived from seamounts resting on the descending Triassic oceanic slab (Hoxha, 2001).

Detailed structural mapping reveals that the deep mantle section in both massifs was harzburgitic and that the major differences between the two ophiolitic belts are restricted to the uppermost mantle and lower crustal section (Nicolas and Boudier, 1999). These are typically «ophiolitic» in the eastern massifs, being composed of a thick dunitic transition zone rich in basaltic impregnations and chromite deposits overlain by a lower crust of layered gabbros. In contrast, in western massifs the uppermost mantle is composed of highly strained to mylonitic lherzolites which originate from more depleted harzburgites by impregnation and tectonic dispersion of melt during deformation occurring at $1000^{\circ}-800^{\circ} \mathrm{C}$. Layered gabbros are locally absent, and the crust can be reduced to diabase dikes or sills and extrusives. The contrast between the eastern and western massifs is ascribed to successive episodes of magmatic and amagmatic spreading in a slow spreading environment (Nicolas et al., 1999). Furthermore, an undisturbed lateral transition exists between the western and eastern-type ophiolites, as seen in the western part of the Bulqiza and Shebeniku massifs (Manika, 1994; Manika et al., 1997; Bebien et al., 1998). In some areas this transition zone is complicated by eastward-dipping thrusts, backthrusts and sub-vertical faults, which led to the contact previously being interpreted as a regional thrust (Beccaluva et al., 1994). Robertson and Shallo (2000) suggested that the western and eastern-type ophiolite formed together and were emplaced as a single thrust sheet. Gradually the ophiolites moved westwards over the continental crust, overthrusted the Krasta-Cukali zone. The uppermost part of the western and eastern vol- 
canic ophiolite is overlain by a remarkable deposition, a «block-in-matrix-type» mélange set in an argillite matrix, considered to be Late Jurassic-Early Cretaceous in age (ISPGJ-IGJN 1982; Shallo 1984; Shallo et al., 1985; Hoxha, 2001).

The nature of the contact between the Krasta-Cukali zone and the Mirdita zone is variable in different areas, ranging from an eastwarddipping thrust (e.g., Miraka, central region; Voskopoja, southern region), to a high-angle fault (e.g., Hajmeli, northern region). By contrast, the contact of the eastern-type ophiolite with the Korabi zone to the east varies from a high to a moderate-angle west-dipping reverse fault zone (fig. 11a,b), to a westward-dipping low-angle thrust (e.g., Bulqiza ophiolitic massif, central region), or an overturned fault (e.g., Selishte, Kolesjani, Luma R., northern region). The majority of these fault contacts were active during the Early Tertiary. Taking account of sub-surface evidence (Frasheri et al., 1996), the western ophiolite contact is regionally a relatively gently inclined thrust $\left(<45^{\circ}\right)$, whereas the eastern contact is steeper $\left(>50^{\circ}\right)$.

\section{Data acquisition and reduction}

TMF intensities were measured over various campaigns during the period 1990-1994 by the Magnetometry Department of the CGGE, Tirana. A total of 25460 magnetic stations were measured using a MP-2 proton precession magnetometer (resolution $0.1 \mathrm{nT}$ ), covering most of the Albanian territory which is about 28000 $\mathrm{km}^{2}$ (Angelopoulos and Bushati, 1993) (fig. 4). The coordinates and the elevation of the stations were extracted from the topographic map with scale $1: 25000$. The accuracy of the measurements was $\pm 25 \mathrm{nT}$ for the Internal Albanides and $\pm 10 \mathrm{nT}$ for the External Albanides (Angelopoulos and Bushati, 1993).

The distribution of magnetic stations is depicted in fig. 4 and was not regular due to the rugged topography of the country. At the region of Kukesi $(10 \times 12 \mathrm{~km})$ for example, sampling was quite dense with measurements obtained every $100 \mathrm{~m}$ (a total of 8350 points in this region). Conversely, the Bulqiza Massif was not covered with a dense grid: the profiles in this zone were $2-3 \mathrm{~km}$ apart and the magnetic stations were every $500 \mathrm{~m}$.

At the ophiolitc massifs of Lura, Shebeniku and Gjinar the measurements were also obtained on profiles positioned $2 \mathrm{~km}$ apart and stationed every $500 \mathrm{~m}$. Over the Puka Massif the measurement grid was every $500 \mathrm{~m}$. The External Albanides (western part of the country) were covered by a sparse grid, with stations every 500-1000 m, while some empty corridors, 5-10 km wide, exist at the southern part of the country. Due to the very rough topography

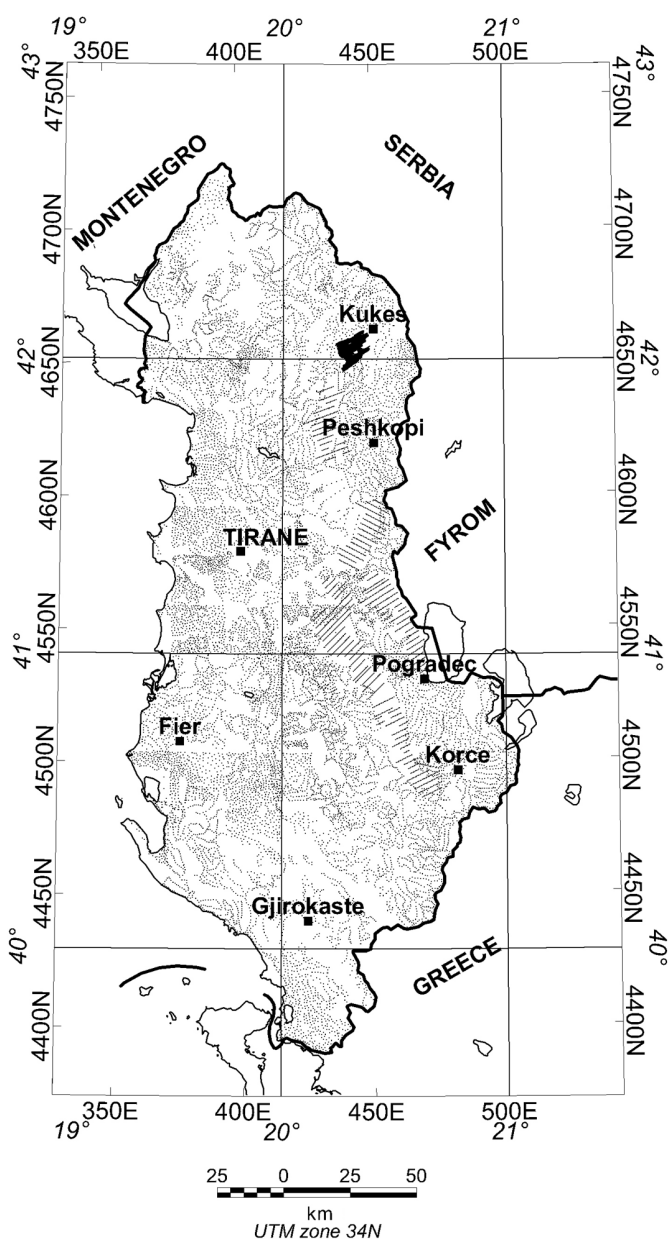

Fig. 4. Location of the ground magnetic stations. 


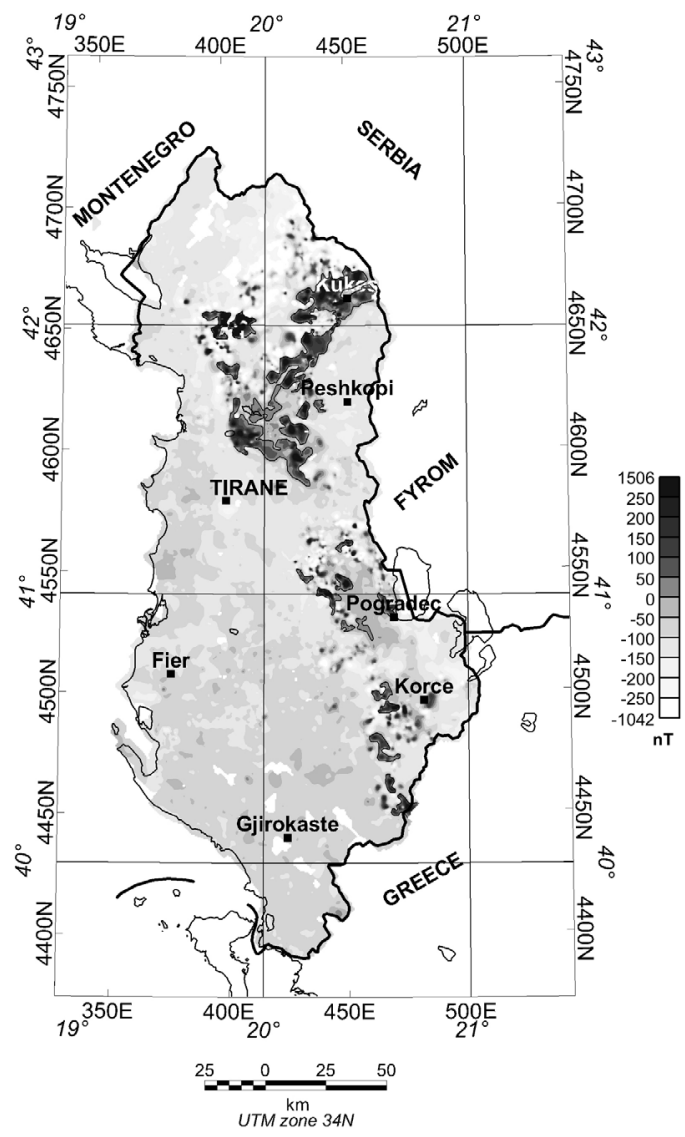

Fig. 5. The residual total magnetic field anomaly map of Albania.

in the area of the Albanian Alps $(20 \times 15 \mathrm{~km})$ no data exist at this region.

Griding was performed using a minimum curvature algorithm and with constant grid spacing equal to $500 \mathrm{~m}$. The measured data were corrected and reduced for the 1990.4 epoch utilizing the IGRFGRID program (Phillips, 1997). The Definite Geomagnetic Reference Field (DGRF) was calculated and then removed from the grided data. Furthermore, a planar regional trend was removed by the use of a least squares algorithm. The planar trend represents long wavelength components rising from topography, regional features and magnetic core fields not adequately be removed by the DGRF model used. The resulted residual total field anomaly map, on which the data enhancement techniques and interpretations were applied, is shown in fig. 5.

\section{Rock magnetic properties}

Some rock samples were collected from the most representative outcrops of the ophiolitic rocks in order to study their magnetic properties. These values were used as reference for the modelling of the magnetic sources.

Crustal magnetic anomalies reflect the spatial variation of the total magnetization of the rocks. To understand the origin of this variability it is necessary to know the magnetic properties of the rocks.

Total magnetization $\boldsymbol{T}$ is the sum of two vectors: remanent magnetization $\Delta \boldsymbol{F}$ (Natural Remanent Magnetization, NRM) and induced magnetization $\boldsymbol{F}$. That is, $\boldsymbol{T}=\Delta \boldsymbol{F}+\boldsymbol{F}=\Delta \boldsymbol{F}+\kappa / \mu \boldsymbol{B}$, where $\kappa$ is the magnetic susceptibility of the rock, $\mu$ is the magnetic permeability and $\boldsymbol{B}$ is the Earth's magnetic induction. In ophiolitic rocks the NRM is mostly TRM (Thermal Remanent Magnetization) and CRM (Chemical Remanent Magnetization). TRM is usually primarily acquired when rooks cool down below their Curie temperature and CRM can be either primary or secondary and is acquired when the rocks are subjected to chemical transformation, recrystalization etc. There is evidence of strong chemical transformation of the ophiolitic rocks in Albania (Shallo et $a l ., 1989)$ that lead to the existence of the CRM in these rocks (Frasheri, 1989).

Measurements of the remanent magnetization and the magnetic susceptibility were performed on the ophiolitic rock samples extracted from different ophiolitic outcrops in Albania (fig. 2). Magnetic susceptibility and magnetization have been measured on 84 rock samples collected from 10 different sampling sites with harzburgites, dunites, gabbros, basalts and diorites outcrops (fig. 2).

The results of the magnetic susceptibility and NRM measurements, which were carried out on those samples, are shown in table I. The results agree with the work of Frasheri (1989) who measured the induced and remanent mag- 
netization of some ultrabasic rocks calculating also the $Q$ (Koenigsberger ratio) on 700 samples in the sense that the magnetism of ultrabasic rocks varies in a broad band of values conditioned by the presence of ferromagnetic minerals. The ultrabasic rocks appear to be ferromagnetic with broadly varying values of magnetic susceptibility and NRM, both in amplitude and direction.

The harzburgites of the Bulqiza Massif have the lowest magnetic susceptibility (average $700 \times 10^{-5}$ units SI), whereas in the Lura Massif they exhibit higher values of susceptibility $\left(2200 \times 10^{-5}\right.$ units SI, table I). When these rocks are serpentinized, i.e. undergoing a process which causes the creation of secondary magnetic phases, the magnetic properties are much stronger. In this case, magnetic susceptibility reaches very high values $\left(e . g ., 7500 \times 10^{-5} \mathrm{SI}\right)$.

Dunites have a magnetic susceptibility higher than the non-serpentinized harzburgites. Four dunitic samples from the site of Kalimash exhibit high magnetic susceptibility, around $2000 \times 10^{-5}$ units SI (table I).

Gabbros seem to be weakly magnetized. The magnetic susceptibilities of the Gabbro samples at Bulshar are lower than those of the non-serpentinized harzburgites. However, the growth of the amount of magnetite in gabbros enhances their magnetic susceptibility and they can become strongly magnetic. The magnetic susceptibility, as in the Gabbro samples from the site of Bozhaj, changes in a very broad limit, e.g., from $200-400$ to $5000 \times 10^{-5}$ and the maximum values are of the order of $35000 \times 10^{-5}$ units SI.

The basalts are comparable to non-serpentinized harzburgites. But in some samples very high values of $\kappa$ were found e.g., $1500 \times 10^{-5}$ units SI, the average value being in the order of $600-700 \times 10^{-5}$ units SI.

The susceptibility measurements indicate a high degree of variability in magnetic properties within the same rock type and between different rock types. This variability may be caused by different magnetic phases with varying concentration. Magnetic minerals in plutonic rocks mainly occur as intergrowth and/or as inclusions in mafic minerals like olivine and pyroxene.

The inclination and declination of the remanent magnetization of the samples was also found to be very scattered and thus we were not able to extract any reliable conclusion about the direction of the remanent magnetization vector. Note that Frasheri (1989) observed similar behaviour.

The Koenigsberger ratio for the most of our samples was less then one (table I). Exceptions are shown by samples taken from Kalimash $(Q=9.8)$ and some samples taken from Bozhaj $(Q=1.82)$. Also Frasheri (1989) mentioned that the Koenigsberger ratio was less than one for $57 \%$ of the samples from dunites and $47 \%$ from hatzburgites where the ratios were 0.5 and 0.6 , respectively. As a result, for the transformations of the magnetic field and modelling of magnetic sources we considered that the magnetization of the ophiolites was of induced type.

Frasheri et al. (1991) suggested that the sediments which surround the ophiolitic belts, and belong to the adjacent tectonic zones (Korabi and Krasta-Cukali), are characterized by very low magnetic susceptibility values. Their values are of the order of $5-10 \times 10^{-5} \mathrm{SI}$ and they rarely reach values as high as $100 \times 10^{-5}$ SI. Comparison of the magnetic properties of the rocks in Albania suggest that, as expected, intrusive rocks are more magnetic than effusive rocks and sediments and therefore they are responsible for the large magnetic anomalies in the area. The different kinds of intrusive rocks have magnetic properties that vary from practically nonmagnetic to very highly magnetic materials. Thus, the values to be used for the modelling purposes must be selected taking into account this fact.

\section{Data processing}

The map of the residual total magnetic field anomaly of Albania is shown in fig 5. The total field magnetic anomalies associated with ophiolitic rocks are clearly identified by their positive high amplitude values. However, within the ophiolite belts the anomaly pattern is complex due to the superposition of many high-amplitude anomalies of different wavelengths. This is expected, since we have magnetic sources with different dimensions, magnetization and burial depth. 
The most remarkable features in this map are the strong anomalies associated with almost every ophiolithic outcrop and the weak anomalies that surround the ophiolithic belts margins. The stronger anomalies are correlated with the Kukesi, Lura, Puka and Bulqiza massifs with maxima up to $800 \mathrm{nT}$. The Puka Massif in particular, is characterized by high frequency anomalies. At the Shebeniku and Gjinar massifs the anomalies are of smaller magnitude at about $400 \mathrm{nT}$ (fig. 5). The northern part of the Tropoja Massif and the Central Mirdita zone over the volcano sedimentary series are characterized by magnetic anomalies with low magnitude. Over the sedimentary basins of the Quaternary depression of the Mirdita zone, which are the Burreli to the north and the Librazhd-Moker to the south, anomalies of moderate magnitude up to 150 nT with dominant low frequencies occur. This provides evidence for the continuation of the ophiolites under these basins.

The magnetic anomalies correlated with the ophiolitic belts of the Mirdita zone are separated in a northern and a southern part by a corridor, which coincides with the Shengjergji flysch corridor (fig. 2). This tectonic unit played a significant role in the geology of Albanides. Geophysical data (Frasheri et al., 1995) show that the Shengjergji flysch corridor, represents a structural carbonatic-terrigeneous without ophiolites under the flysch deposits. The disruption of the magnetic anomalies in this area suggests that the ophiolitic belts of the Albanides are tectonically split into two parts. Finally in the adjacent (to the Mirdita zone) Korabi and Krasta-Cukali zones no significant magnetic anomalies are present.

In order to obtain some information about the location and nature of the magnetic sources the data were subjected to various transformations. Low pass filtering, upward continuation, directional derivatives, reduction to the pole and pseudogravity transformations were applied in order to enhance the data. Finally, the «terracing» operator (Cordell and McCafferty, 1989) was applied to delineate the horizontal boundaries of the magnetic sources.

The ophiolites comprise a $30-70 \mathrm{~km}$ wide belt, thus, the longest wavelength anomalies generated from these sources should have a wavelength larger than $30 \mathrm{~km}$. A low pass filter with cut off wavelength of $25 \mathrm{~km}$ was considered appropriate to isolate the anomalies caused by the relatively deep structures of the ophiolitic belt.

The low pass filtered map is shown in fig. 6 . The anomalies which dominate the filtered map are centered over the outcrops of the ophiolitic massifs of Kukesi, Lura, Bulqiza, Puka to the north and Shebeniku and Gjinar to the south. The strongest anomaly is the one over the massif near the town of Kukesi. The anomaly at the Puka Massif remains pronounced despite filtering. To the south there are some isolated low

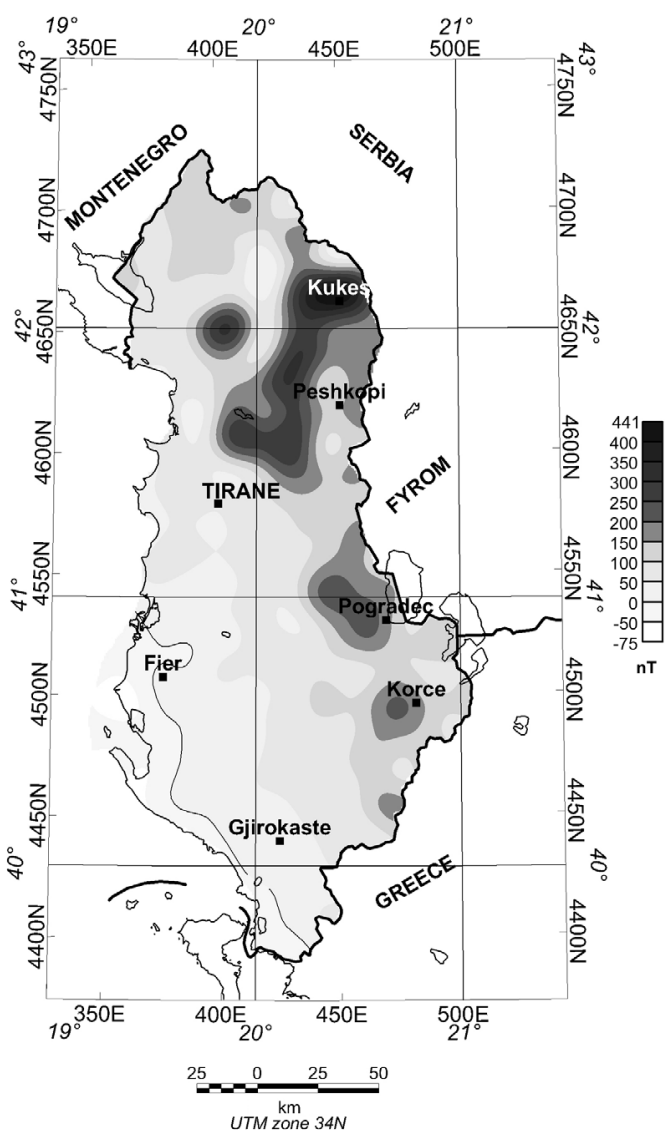

Fig. 6. The total magnetic field anomaly filtered by removing all wavelengths smaller then $25 \mathrm{~km}$. 
magnitude anomalies centered over the ophiolitic massifs. Overall, the anomalies to the north of the country are more extended and of higher magnitude than those to the south.

The upward continuation process favours the long wavelength anomalies (Henderson and Zietz, 1949), caused by deep structures. Figure 7 depicts the total magnetic field continued upward to the altitude of $2500 \mathrm{~m}$ above ground level. The ground surface, where the measurements were taken, is considered flat for this operation. The strongest anomalies of the upward continued field are observed in the northern part especially over the eastern belt.

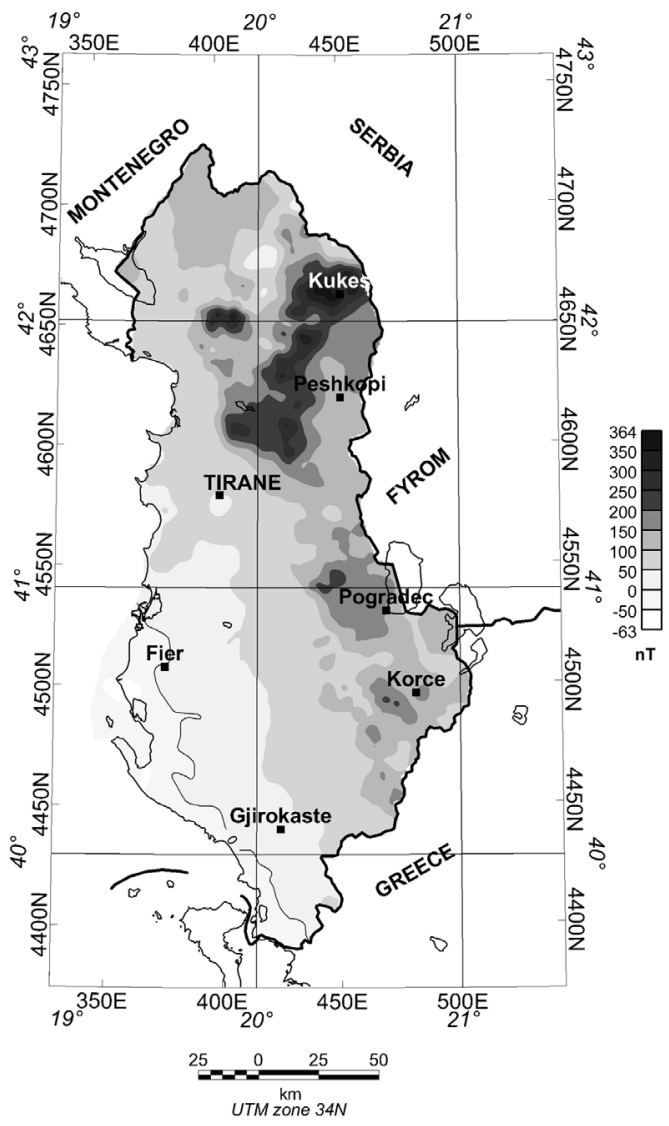

Fig. 7. Upward continuation of the total magnetic field anomaly to $2500 \mathrm{~m}$.
Positive gravity anomalies are located over surplus mass concentrations but the same is not necessary true for magnetic anomalies when the magnetization and the ambient field are not both directed vertically. In general the magnetic anomalies are dipolar and asymmetrical in shape. This complexity can be eliminated by using reduction to the pole and pseudogravity transformations (Baranov, 1957; Arkani-Hamed, 1988).

The reduction to the pole operation transforms the magnetic anomaly to the anomaly that would be measured at the north magnetic pole, where the ambient field is directed vertically down. The reduced to the north magnetic

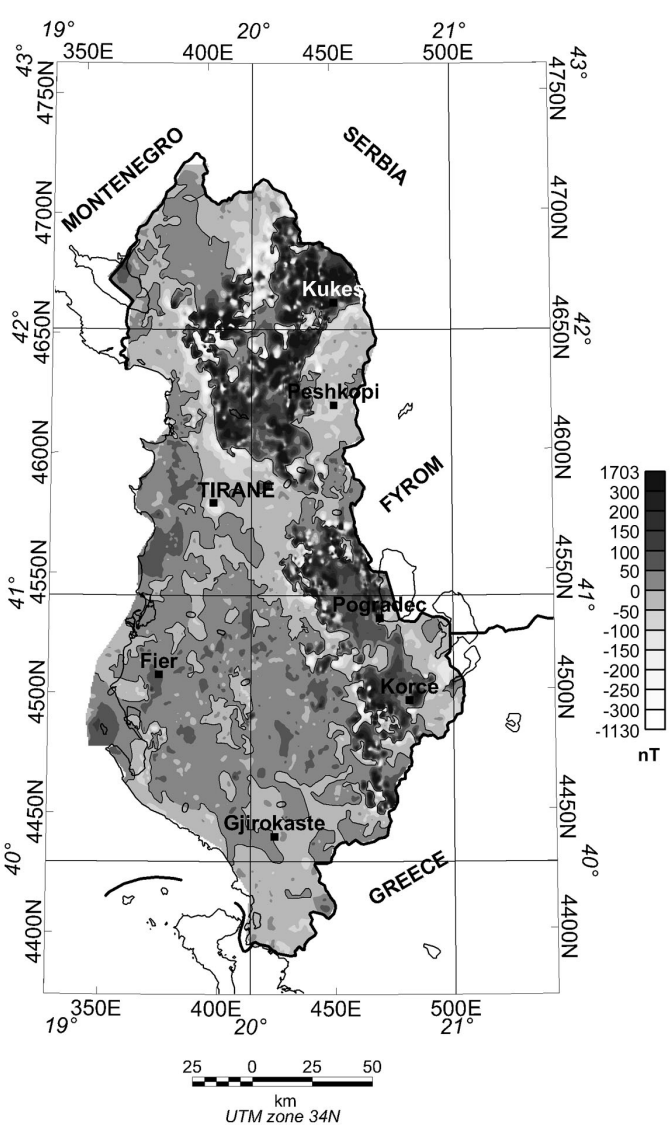

Fig. 8. Reduced to the pole total magnetic field anomaly of Albania. 
pole field of Albania is shown in fig. 8. The anomalies at the center of the ophiolitic massifs have much larger magnitude compared with the small anomalies surrounding the ophiolitic belts.

Cordell and McCafferty (1989) described a technique to produce a kind of equivalent source from measured gravity or magnetic data. This is an iterative technique that transforms the magnetic data into a field comprised of uniform domains separated by abrupt boundaries. Thus, density or magnetization within the equivalent layer should remain constant except across these abrupt boundaries. The result produces pseudo-geological boundaries since it derives from the processing of a physical property. The so-called «terracing» operator is not equated to downward continuation since it does not admit the presence of a transition zone between the boundaries of the distinguishable domains. The operation is based on the sign of the curvature of the potential field at any particular point. The value of each point of a data grid is revised upwards or downwards based on the algebraic sign of the curvature (i.e. the second vertical derivative) at that point. Repeated adjustments are made until the terraced effect is achieved. The resulting «terrace» does not directly reflect density or magnetization but can be scaled in order to do so. This scheme was applied to the pseudogravity field of Albania and the result is shown in fig. 9. The result indicates that the ophiolites are mainly confined at depth to the area in which they outcrop. The only exception is seen in the Lura Massif where there is a small extension of the «terraced» boundary east of the geologic outcrop. The «terraced» boundaries at the eastern side of the belt are very sharp in comparison with the western ones. This is justified by geological evidence that suggest that the edges of the ophiolitic massifs at the eastern side are almost vertical.

The second vertical derivative (Evjen, 1936; Elkins, 1951) of a potential field measured on a horizontal surface is obtained by multiplying the spectrum of the anomaly by the square of the wavenumber. This procedure helps to better resolve and accentuate shallow sources since the higher wavenumber anomalies are magnified.

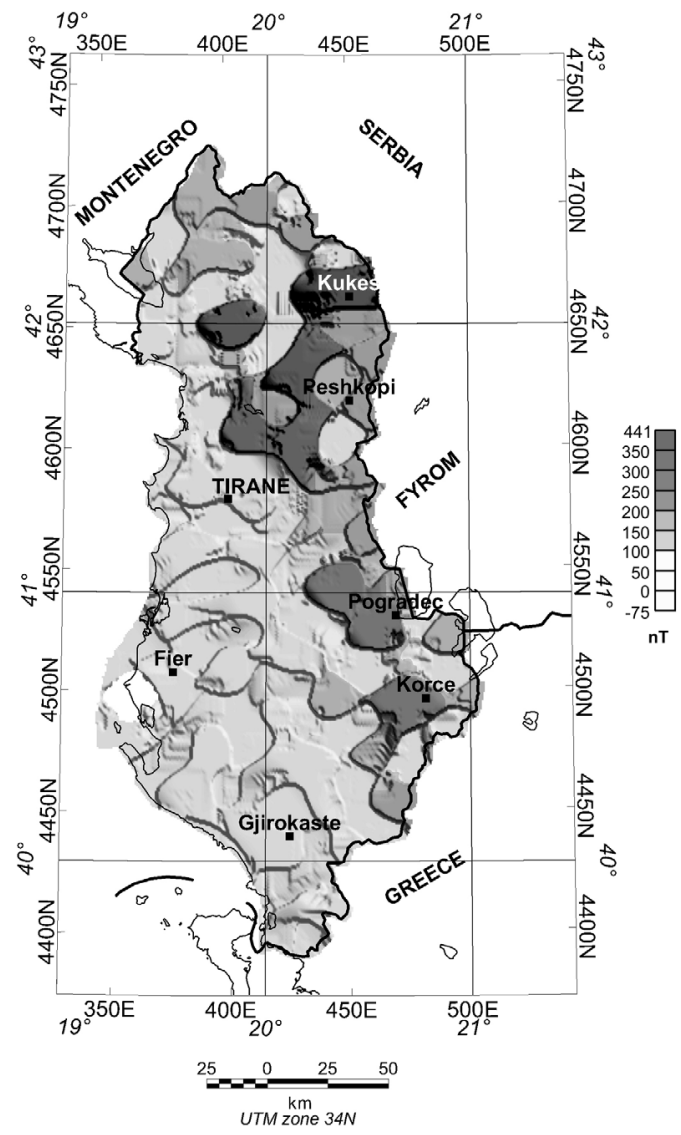

Fig. 9. The result of «terracing» applied to the total field magnetic anomaly of Albania after the removal of all wavelengths smaller than $20 \mathrm{~km}$.

The steepest horizontal gradient of pseudogravity or reduced to the pole magnetic anomaly caused by a tabular body tends to overlay the edges of the causative body. Actually, the steepest gradient will be located directly over the edge of the body if the edge is vertical and far removed from all other edges or sources. We calculated the gradient by applying simple finite-difference formulas to the magnetic measurements by first reducing them to the north magnetic pole and the results are presented in fig. 10. The maxima of the horizontal gradient are calculated and plotted by black dots on fig. 10. The interpolation of these max- 
ima, showing the steepest gradient values, helps to delineate the edges of the magnetic sources. A range of maxima is well correlated with the eastern edge of the ophiolites (fig. 10), where the greatest values of the maxima coincide with their outcrops. This result indicates again that the eastern edge is nearly vertical.

Finally, taking into account the information provided by the above described techniques,

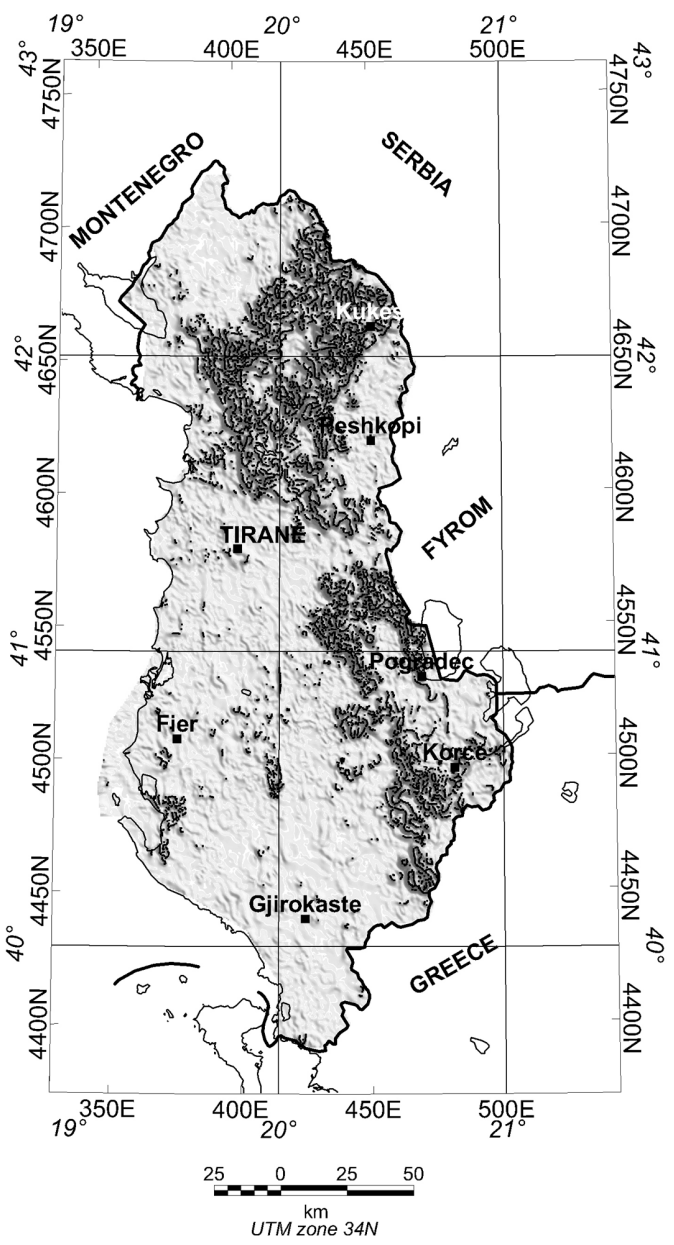

Fig. 10. The second horizontal derivative of the magnetic anomaly of Albania. The derivative is calculated after reducing the anomaly to the north magnetic pole. The maxima of the gradient are denoted by black dots. modelling was attempted along selected profiles (fig. 2), perpendicular to the ophiolitic belts. A 2.5D forward method was applied to fit the synthetic anomaly caused by a certain model to the anomaly observed along the profiles. This procedure provides the magnetic anomaly along a profile assuming that the anomalous bodies are finite prisms of polygonal cross-section and uniform magnetization. The prisms were assumed to have their $y$ axis $20 \mathrm{~km}$ long at either side of each profile. The program SAKI (Webring, 1985) was used for the inversion of the observed magnetic data. It uses semi-automatic Marquardt inversion of gravity and magnetic profiles.

The modelled ophiolites were grouped at certain bodies differing in their magnetic susceptibility values. The initial susceptibility values used in the modelling procedure were taken from table I. The horizontal boundaries of the bodies, which were taken from previous processing steps, were used as constrains in the inversion scheme. Depths to the top of ophiolites were calculated by means of spectrum analyses, while the ophiolites outcrop were used as constraints. Depths to the bottom of magnetic sources, shapes and final susceptibility values were calculated by means of inversion.

In our models we assume that the bottom part of the ultramafics in both ophiolitic belts is predominated by harzburgites. Harzburgites constitute also the upper part of the ultramafics at the eastern-type ophiolite, while lherzolites constitute also the upper part of the ultramafics at the western-type ophiolite, both characterized by relatively low susceptibility values, ranging from 200 to $1700 \times 10^{-5} \mathrm{SI}$. The upper part of the ultramafic sequence of the westerntype ophiolite is predominated by plagioclase dunite and plagioclase lherzolite and hornblendites, whereas that of the eastern-type is thicker and mainly composed of transitional dunites and layered chromites. Crustal cumulate sequence in the eastern-type ophiolite is predominated by gabbros, which exhibit high magnetic susceptibility values, while in the western-type is troctolitic. Taking all the above into account we split the ophiolites of Midrita zone into a number of simple modelling bodies with differing magnetic susceptibility, in order 
to simulate the magnetic anomalies. These modelling bodies do not correspond to single ophiolitic formations, but to ophiolitic blocks which include the ultramafic and crustal ophiolitic sequences. Their susceptibilities are representative for the whole sequence.

Profile Pr1 (fig. 2) passes through westerntype ophiolite. Two modeling bodies with susceptibilities that are slight different (fig. 11a) were used in this model. The thickness of low magnetic susceptibility Neocene molassic deposits, which cover the ophiolites range from 1.0 to $1.5 \mathrm{~km}$. The thickness of ophiolites at this

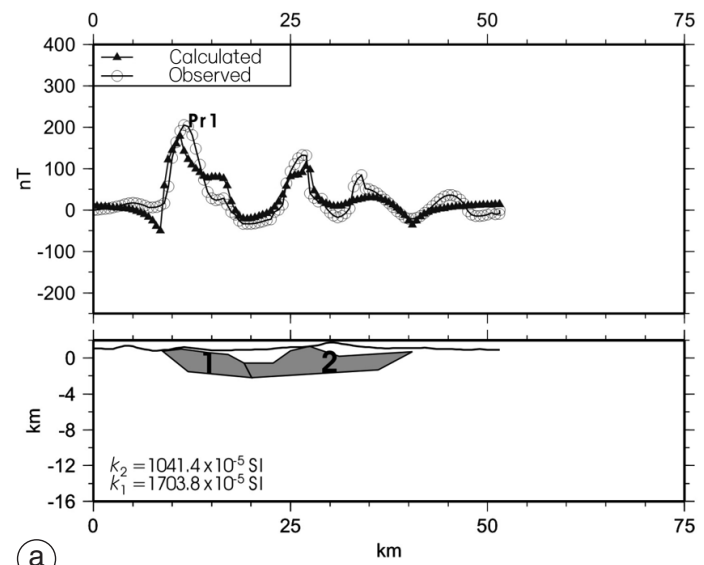

(a)

$\mathrm{km}$

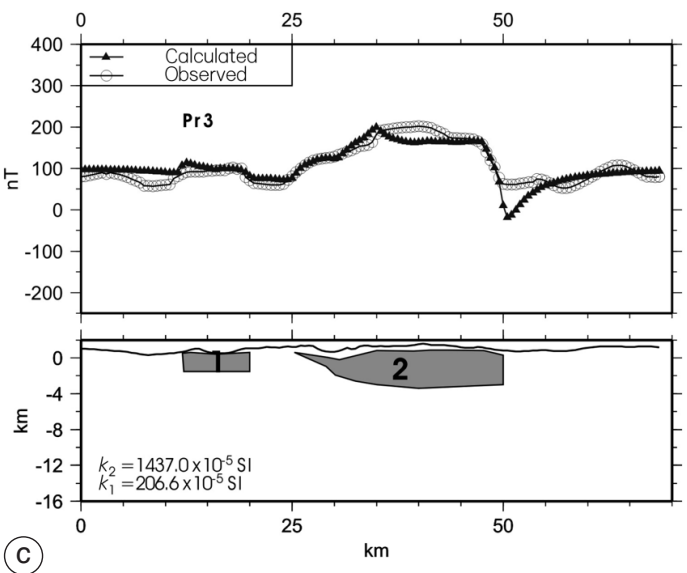

part of Albania (fig. 2) does not exceed $3 \mathrm{~km}$. In profile Pr2 (fig.2) the modeling bodies (fig. 11b) are similar to those of Pr1, their thickness does not exceed $4.5 \mathrm{~km}$ and the sedimentary cover is less than $1 \mathrm{~km}$ thick. The modeling body 1 in Pr3 (fig. 11c), which correspond to Devolli Massif, appears detached from the main ophiolitic body 2, and has relatively low susceptibility. Body 1 in Pr4 (fig. 11d) corresponds to western-type ophiolite, while body 2 to eastern-type. They have similar magnetic properties and their thickness is about $4 \mathrm{~km}$. The thickness of the sedimentary cover in this profile is about

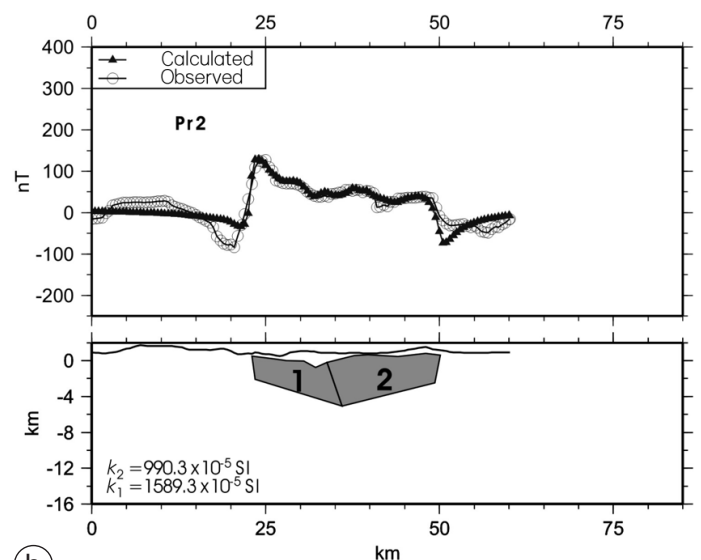

(b)

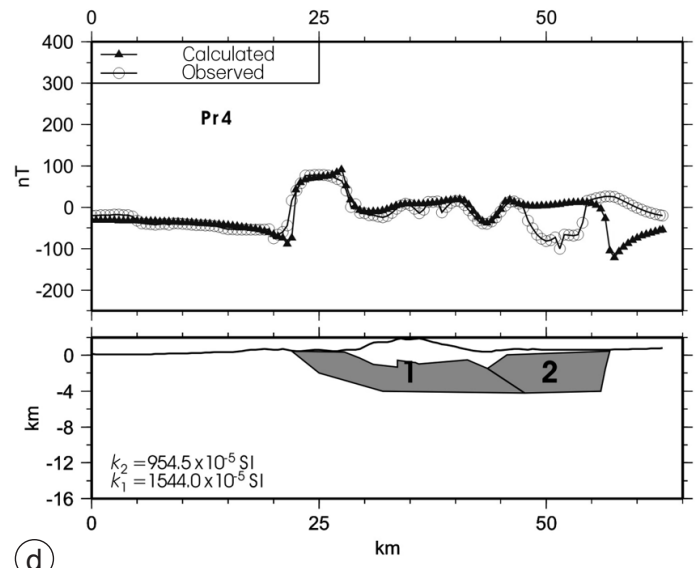

(d)

Fig. 11a-d. 2.5D modeling of the magnetic sources along the profiles $\operatorname{Pr} 1$ (a), $\operatorname{Pr} 2$ (b), $\operatorname{Pr} 3$ (c) and $\operatorname{Pr} 4$ (d) (see fig. 2 for the location of profiles). 

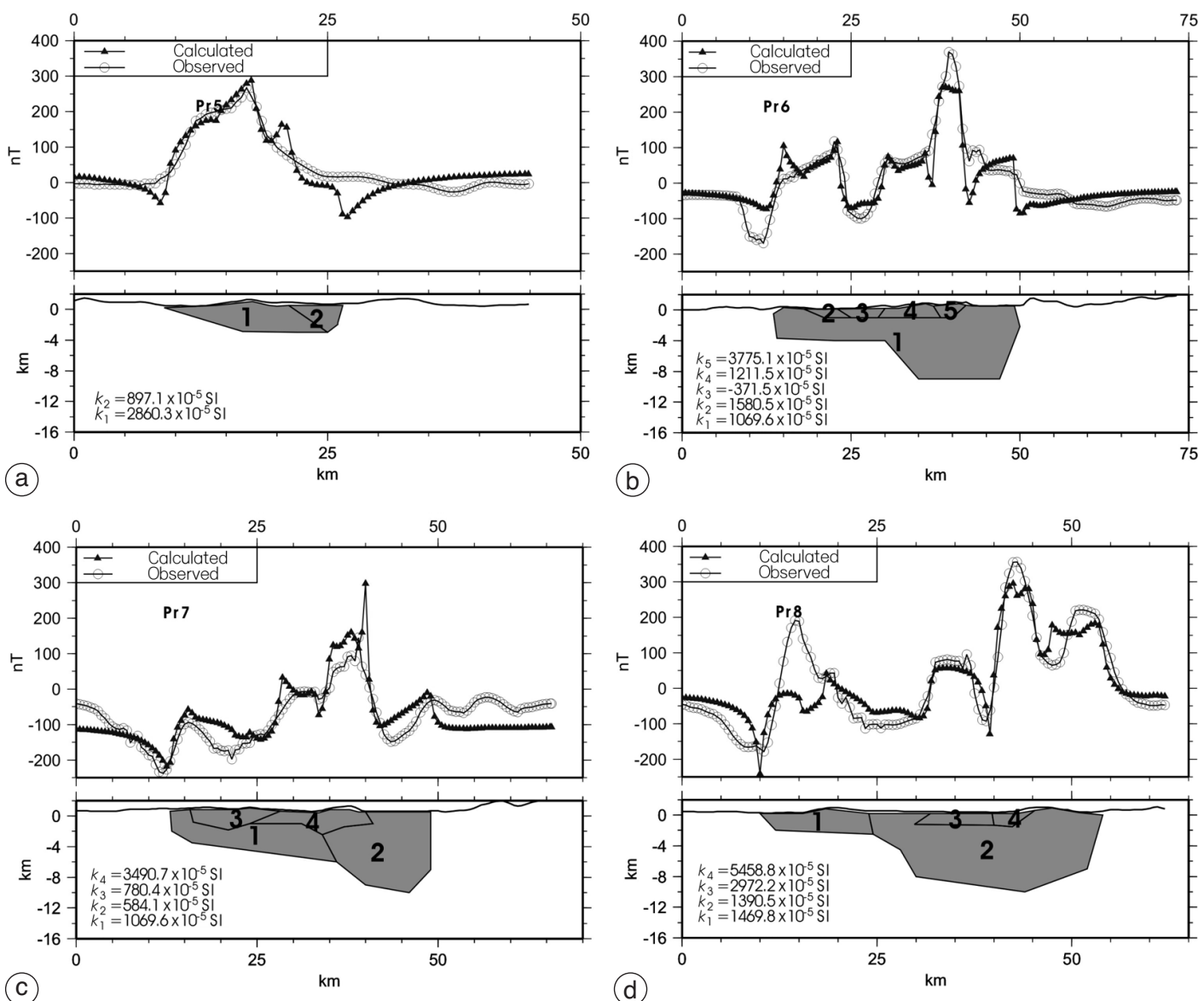

Fig. 12a-d. 2.5D modeling of the magnetic sources along the profiles $\operatorname{Pr} 5$ (a), $\operatorname{Pr} 6$ (b), $\operatorname{Pr} 7$ (c) and $\operatorname{Pr} 8$ (d) (see fig. 2 for the location of profiles).

$2 \mathrm{~km}$. In profile Pr5 (fig. 12a) modelling bodies 1 and 2 correspond to dunite and harzburgite rich bodies. Dunite exhibits three times higher susceptibility values than harzburgite. The thickness of the ophiolites is less than $4 \mathrm{~km}$.

At the northern part of Albania the ophiolites become thicker (10-12 km). We introduce some modeling bodies on top of the main ophiolite blocks (correspond to gabbroitic, basaltic and peridotic bodies) in order to compensate the high frequency part of the magnetic field (fig. 12b-d, profiles 6-7-8), which is characterized by higher magnetic properties. Their depth extent is limited $(1.5-3 \mathrm{~km})$. Those bodies influence the abrupt fluctuation of the observed field. The overall thickness of the ophiolites is increasing, reaching up to $12 \mathrm{~km}$ at the northeastern part where the Kukesi and Lura massifs crop out, while the western part remains relatively thin.

The nearly vertical boundaries of the eastern massifs used in the models, after the interpretation of the horizontal gradient as discussed above, appear to produce a very good fit with the observed data. This suggests the existence of nearly vertical faults. The thickness is reducing 
from west to east. This is in line with the overthrust structure of the ophiolites at the western part, over the sediments of the Krasta-Cukali zone. In general, the thickness of the eastern belt becomes smaller from north to south. However, in the southern part, the thicknesses of the eastern and western belts are the same.

\section{Discussion and conclusions}

We have compiled the total field magnetic map of Albania from ground measurements. The magnetic datasets used do not cover the entire Albanian region and have variable density, thus we had to interpolate and regrid the data.

Processing and interpretation techniques were applied to enhance the information from the magnetic data and to produce structural and geological models of the ophiolitic belts in Albania, which are characterized by strong magnetic anomalies, compared to the surrounding formations. From our study and from previous geological and geophysical work in this area, we conclude that the ophiolitic belts in the Albanides are tectonically split into two parts, a north and a south part, from Shengjergji corridor under which there are no ophiolitic bodies. The compiled magnetic map (fig. 5) supports the previous geological studies which suggest that there is no continuation of the ophiolites under the sediments of the Shengjergji corridor (absence of strong magnetic anomalies). Gabbros exhibits the highest magnetic susceptibility values. It is two to three times higher than the susceptibility of the harzburgites. The sedimentary cover has thickness that is about 1000$1500 \mathrm{~m}$. The eastern ophiolitic belt has the greater thickness at the northern part. It is about $12 \mathrm{~km}$ near the Kukesi and Lura massifs. The magnetic sources have smaller thicknesses in the western belt at the northern part. Near the Gomsiqe Massif the thickness does not exceed $3 \mathrm{~km}$. There is an abrupt change in thickness in the northern part from the western to the eastern belts. From south to north the thickness of the eastern belt increases. Steep eastern boundaries of the ophiolitic bodies appears at the magnetic models correspond to nearly vertical faults.

\section{Acknowledgements}

This work was carried out as part of the Seis-Albania project (No. 972342) in the framework of the NATO «Science for Peace» program. We want to thank Prof. Anastasia Kiratzi and Prof. Betim Muco for the inclusion of this work in the «Science for Peace» program and the employees of CGGE (Centre of Geophysical and Geochemical Exploration) in Tirana, Albania for their help. Prof. Alfred Frasheri, Prof. Minella Shallo and Dr. Simo Spassov for their help and useful suggestions.

\section{REFERENCES}

Angelopoulos, A. and S. Bushati (1993): Unification of gravity, magnetic, radioactivity of Albania, Greece and other Balkan's, Final Report CGGE, Tirana, Albania.

ARAPI, S. (1982): The study of the relationship of the gravity field distribution in the Ionic, Kruja and Sazani outer tectonic zones in the context of the geologic-geophysical researches of the perspective structures for oil and gas, MSc. Thesis, Geophysical Enterprise, Fier, Albania.

ARKANI-HAMED, J. (1988): Differential reduction to pole of regional magnetic anomalies, Geophysics, 53, 15926000 .

Aubouin, J. (1959): Contribution a l'etude geologique de la Grece septentrionale. Les confins de l'Epire et de la Thessalie, Ann. Geol. d. Pays Helen., 10, 1-525.

Aubouin, J. and I. Ndojaj (1964): Regard sur la géologie de l'Albanie et sa place dans la géologie des Dinarides, Bull. Soc. Géol. Fr., Ser. 7, VI (6), 593-625.

BARANOV, V. (1957): A new method for interpretation of aeromagnetic maps, pseudogravimetric anomalies, Geophysics, 22, 359-83.

Bebien, J., M. Shallo, K. Manika and D. Gega (1998): The Shebenik Massif (Albania): a link between MOR and SSZ-type ophiolites?, Ofioliti, 23, 7-15.

Bushati, S. (1988): Regional study of gravity field scattering in the inner Albanides, for the tectonic and mineralogenic regioning, MSc. Thesis, Geophysical Enterprise, Tirana, Albania.

Cordell, L. and A.E. MCCAFFERTy (1989) A terracing operator for physical property mapping with Potential field data, Geophysics, 54, 621-34.

Dede, S., R. Shehu and M. Shallo (1966): Magmatizmi intruziv me lhgiperi dhe lidhya e mineralizimit me te, Permbledhje. Stud., 3, 1-15.

ELKINS, T.A. (1951): The second derivative method of gravity interpretation, Geophysics, 16, 29-50.

EvJeN, H.M. (1936): The place of the vertical gradient in gravitational interpretations, Geophysics, 1, 127-136.

FRASHERI, A. (1989): Physical properties of chrome iron ore and ultrabasic rocks in the Albanides, in Leobener Hefte zur Angewandten Geophysik, 2, 100-125. 
Frasheri, A., V. Lubonja, P. Nishani, S. Bushati, A. HySENI and V. LECI (1991): Les donnes geophysiques sur les relation entre les zones tectoniques des Albanides a terre et sur le plateau continental de la mer Adriatique, in Colloque sur la Geologie de l'Albanie (Paris, Soc. Geol. Fr.).

Frasheri, A., P. Nishani, S. Bushati and A. Hyseni (1995): Geophysical study of the Albanides, Boll. Geofis. Teor. Appl., 37 (146), 159-178.

Geology of Albania (1982): Notes of the new geologic map of Albania 1:200000, I.S.P.G. J. Tirana, p. 342

Henderson, R.G. and I. ZIETZ (1949): The upward continuation of the anomalies in total magnetic intensity fields, Geophysics, 14, 517-534.

HoxнA, L. (2001): The Jurassic-Cretaceous orogenic event and its effects in exploration of sulfide ores, Albanian ophiolites, Albania, Eclogae Geol. Helv, 94 (2001) 339-350.

ISPGJ-IGJN (1982): Geology of Albania, Tirana, Albania (published in 1990, pp. 492, in Albanian).

LubonjA, L., A. Frasheri and A. QIRINXHI (1977): The gravity and magnetic surveys usage for regional geological studies in Albania, Summary of Studies, 7, 49-62.

ManiKA, K. (1994): Petrologie du massif ophiolitique de Shebenik (Albanie), Ph.D. Thesis, Université Paris-Sud, pp. 297 (unpublished).

MANIKA, K., M. Shallo and D. GEga (1997): The plutonic sequence of Shebenik ophiolitic complex, Albania: evidence for dual magmatism, Ofioliti, 22, 93-99.

NdoJAJ, I.G. (1963): Mbi disa probleme te magmatizmit ne vendin tone, Bil. Shkiperise Nat., 2, 1-13.

NiCOLAS, A. and F. BoudIER (1999): Slow spreading accretion and mantle denudation in the Mirdita ophiolite (Albania), J. Geophys. Res., 104, 15,155-15,167.
NiCOLAS, A. and E.D. JACKSON (1972): Répartition en deux provinces des peridotites des chaines alpines longeant la méditerranée: implications géotectoniques, Bull. Suisse Miner. Petrol., 53, 385-401.

NowACK, E. (1929): Geologische Ubersicht von Albanien, Salzburg.

PhILLIPS, J. (1997): Potential-field geophysical software for the PC version 2.2, U.S. Geol. Surv. Open-File Rep. 97725 .

Robertson, A. and M. Shallo (2000): Mesozoic-Tertiary tectonic evolution of Albania in its regional Eastern Mediterranean context, Tectonophysics, 316 (3), 197-254.

Shallo, M. (1992): Geological evolution of the Albanian ophiolites and their platform periphery, Geol. Rundsch., 81 (3), 681-694.

Shallo, M., Dh. Kote, A. Vranaj and I. Premti (1985): Magmatismi ofiolitile i shqiperise, Ist. SP. Geol., Tirana, Albania.

Shallo, M., Dh. Kote, A. Vranaj and I. Premti (1989): Some petrological features of the ophiolite of Albanides, Bul. Shk. Gjeol., 2, 9-27.

TAshKo, A. (1966): Disa dallime gjeokimike ge verehen brenda shkembinjeve ultrabazike te vendit tone, Permbledhje. Stud., 4, 101-118.

VEIZAJ, V. (1995): The relationship between Albanid orogeny and Apulian platform according to the gravity data, in First Symposium of Oil and Gas, Fier, Albania.

WeBRING, M. (1985): SAKI, a Fortran program for generalized linear inversion of gravity and magnetic profiles, U.S. Geol. Surv., Open-File Rep. 85-122.

(received February 10, 2004; accepted November 11, 2004) 